\title{
Editorial
}

\section{There are people in the forest too}

The relentless demolition of the world's tropical forests causes much concern amongst presentday conservationists. Wildlife conservationists contemplating the problem of tropical forest destruction and the probable extinction of thousands of species could find it dangerously easy to forget and neglect the plight of the indigenous peoples. These peoples are not without their champions, however. Survival International (SI) is one of a number of organisations working to help secure the rights of tribal peoples to survival, to self determination, to representation in all decisions affecting their future, to ownership and use of their traditional lands. Many of these people live in tropical forests and are threatened as much as the wildlife by their destruction. Survival Intemational News No. 7 carries distressing reports on tribal peoples who are 'in the way' of development schemes.

In the Philippines, the army has been bombing and harassing the Igorot tribespeople of the Cordillera of Luzon Island since April 1984. The problems began in the 1970s, when the World Bank initiated a massive hydroelectric scheme in the Chico Valley. Tribal protests at the flooding of ancestral lands were met with violent government crackdowns. The World Bank finally withdrew funding for the dams, but other 'development' schemes have kept the struggle going. Some tribals, lending their support in protest to the New People's Army, have become the target of the latest government violence.

The Malaysian Government, which in 1983 abandoned its plan to build a dam in Taman Negara (National Park) after widespread protests, is now planning a massive hydroelectric project on the Rajang River in Sarawak. Two enormous dams will displace 14,000 tribal people. Logging has already started around one of the proposed dams; the river is silting up, the water is unfit for drinking and the wild animals have fled.

In Brazil, a proposed package of legislation threatens the Yanomami and other Indian groups of Roraima Territory by opening up their lands to private mining companies. In Peru, the Manu National Park, home of hundreds of uncontacted Indians, is threatened by a canal, a road and oil exploration.

Given the obvious coincidence of interests, it seems sensible and appropriate for organisations such as FFPS and SI to collaborate, not only in tropical forest areas, but in other places where tribal people and endangered wildlife coexist. For such a move to be possible, conservationists will have to address a problem that they have largely ignored. In many places, legislation for wildlife conservation has meant hardship for indigenous peoples. For example, although Peruvian Indians generally have been granted rights to land, those that live in national parks and reservesincluding those in Manu National Park-have no rights at all under existing national park legislation. On the other side of the world, in China's Wolong Nature Reserve, some 1800 Tibetans are being evicted from their ancestral land to make room for giant pandas. The pandas are being forced down from the higher altitudes by the current scarcity of bamboo to the lower slopes where most of the Tibetans live.

There is a real dilemma in cases like these. A species at risk of extinction, especially one like the panda which is such a potent conservation symbol, deserves to attract an enormous amount of conservation effort. One could argue that moving people out is justifiable, if the alternative is panda extinction, and that humans are adaptable and will survive. The solution, however, should not be to force a choice between people and wildlife. There must be instead more determined efforts to resolve the conflict in other ways. It is especially saddening when strict conservation practices alienate and bring suffering to the very people who are most ecologically adapted to their environment and in whose hands the habitat would perhaps be safest.

It is time to face up to the problems that conservation legislation can cause for some people whose traditional homelands are also areas of high conservation value. There will always be conflict and there will be times when resolution seems impossible, but the groups fighting for the rights of tribals and the groups seeking to conserve endangered species have much in common. Conservationists must, at least, begin to include threatened peoples in their vision. 